KS. JERZY ADAMCZYK* - RADOM

\title{
BIBLIOTEKI KOŚCIELNE W ASPEKCIE KANONICZNYM
}

\section{Wstęp}

Autorzy listu okólnego Biblioteki w misji Kościoła piszą: „,samo już istnienie bibliotek kościelnych, spośród których niejedne znamionują się długą tradycją i ogromną wartością dla kultury, usprawiedliwia w sposób niepodważalny to zaangażowanie się, z którego Kościół nie chce zrezygnować, świadomy będąc dziedzictwa duchowego udokumentowanego zawartą w księgach tradycją i uznając ją za dobro jednocześnie własne i uniwersalne, oddane w służbę społeczeństwu"1.

To w misji ewangelizacyjnej Kościoła ma swoje podstawy ustawiczna troska, którą wspólnota chrześcijańska otoczyła tworzenie, zachowywanie, wzbogacenie, obronę i wykorzystanie swoich bibliotek. Dowodzi tego stałe przypominanie przez pasterzy Kościoła o tej powinności oraz godna naśladowania troska, jaką niektóre wspólnoty diecezjalne czy też zakonne darzą książki. $Z$ tego samego powodu należy przeciwstawiać się wszystkiemu, co przeszkadza konserwacji i ochronie bibliotek, ich rozwojowi oraz dostępowi do nich i korzystaniu z ich zbiorów ${ }^{2}$.

Wyrazem troski władzy kościelnej o tworzenie, zachowanie, rozwój i ochronę kościelnych zasobów bibliotecznych, są wydawane w tej materii dyspozycje kanoniczne. Poprzedni, jak i aktualny Kodeks milczy na temat bibliotek kościelnych, aczkolwiek z pewnych przepisów można pośrednio wydedukować, że prawodawca powszechny bierze pod uwagę te instytucje prawne. Natomiast wyraźnie o wspomnianych bibliotekach mówią przedkodeksowe, czy pozakodeksowe dokumenty kanoniczne lub mające aspekt prawny.

${ }^{*}$ Ks. Jerzy Adamczyk - dr hab. prawa kanonicznego, prof. Instytutu Teologicznego UKSW w Radomiu.

${ }^{1}$ Pontificia Commissione per i Beni Culturali della Chiesa, Lettera circolare Le biblioteche ecclesiastiche nella missione della Chiesa (19 marzo 1994), nr I, Enchiriděon dei Beni Culturali della Chiesa. Documenti ufficiali della Pontificia Commissione per i Beni Culturali della Chiesa, Edizioni Dehoniane (dalej: Le biblioteche ecclesiastiche), Bologna 2002, s. 201-219, tekst polski: „Fides. Biuletyn bibliotek kościelnych”, 1-2 (1996) s. 31-46.

${ }^{2}$ Por. tamże, nr 1. 3. 
Przedmiotem naszego zainteresowania będzie zagadnienie bibliotek kościelnych. Najpierw uwaga zostanie zwrócona na sprawę pojęcia i rodzajów bibliotek kościelnych, z kolei zostanie naświetlona kwestia zasobu bibliotecznego, wreszcie zostanie omówione zagadnienie organizacji bibliotek kościelnych.

\section{Pojęcie i rodzaje bibliotek kościelnych}

Bp M. Leszczyński jest zdania, że swego rodzaju definicją biblioteki kościelnej są słowa wyjęte z Prezentacji Papieskiej Komisji do spraw Kościelnych Dóbr Kultury, które brzmią: „biblioteki kościelne nie są jedynie świątyniami czystej wiedzy, ale są uprzywilejowanym miejscem prawdziwej mądrości, która poprzez trud tych, którzy we fragmentach stworzenia szukali śladów Boga, opowiada historię człowieka, chwali Boga żyjącego. W konsekwencji nie można zredukować bibliotek do przechowalni książek, ponieważ są to instytucje kulturowe. Biblioteki są wyrazem zainteresowanie Kościoła kulturą każdego narodu i dokumentują proces inkulturacji wiary; odzwierciedlają także procesy formacji filozoficznej, teologicznej, katechetycznej, liturgicznej, pastoralnej, duchowości, prawnej; dają sens uniwersalności i jedności myśli o inspiracji chrześcijańskiej przedstawianej w różnych językach, oprócz greckiego i łacińskiego, mówią o magisterium Kościoła i o skarbcu tradycji kościelnej”3. Oczywiście nie jest to wyczerpujące i adekwatne określenie biblioteki kościelnej, tym bardziej nie jest to definicja kanoniczna.

Skoro biblioteka nie jest zwykłą przechowalnią książek, to powstaje pytanie: czym w ogóle jest biblioteka, a następnie: czym jest biblioteka kościelna, która jest przecież instytucją kanoniczą ${ }^{4}$.

Słownik języka polskiego podaje definicję biblioteki jako takiej: „,biblioteka to instytucja powołana do gromadzenia i udostępniania księgozbiorów", ale także „gmach, lokal takiej instytucji”. Według Nowej Encyklopedii Powszechnej PWN biblioteka to ,instytucja kultury, która gromadzi, opracowuje, przechowuje i udostępnia zbiory biblioteczne oraz informuje o nich. Potocznie także pomieszczenie dla książek (budynek, lokal, meble) i księgozbiór" ". Z. Gaca-Dąbrowska określa bibliotekę jako „instytucję, która pełni określone funkcje społeczne (np. badawcze, edukacyjne, kulturalne itd.) przez planowe gromadzenie, opracowanie i udostępnianie zbiorów oraz informowanie o nich"7.

${ }^{3}$ Pontificia Commissione per i Beni Culturali della Chiesa, Presentatione della Pontificia Commissione, nr 3. 3, Cittŕ del Vaticano 2004, tekst polski: Prezentacja Papieskiej Komisji do spraw Kościelnych Dóbr Kultury, „Biuletyn kościelnych dóbr kultury”, 1 (2005) s. 92-120; M. Leszczyński, Biblioteki kościelne w najnowszych wypowiedziach Papieskiej Komisji ds. Kościelnych Dóbr Kultury, „Archiwa, Biblioteki i Muzea Kościelne” (dalej: ABMK), 83 (2005) s. 33. Pius XII pisze, że biblioteki winny być żywym organizmem, nie zaś martwym składem książek. Adhortatio Apostolica Menti Nostrae (23 septembris 1950), pars III „Acta Apostolicae Sedis”, 42 (1950) s. 657-702.

${ }^{4}$ Okólnik Le biblioteche ecclesiastiche uzasadnia prawny wymiar bibliotek kościelnych przywołując w przypisie 8 szereg dokumentów i norm prawnych odnoszących się do tej rzeczywistości.

${ }^{5}$ Stownik języka polskiego, t. I, Warszawa 1978, s. 157.

${ }^{6}$ Nowa Encyklopedia Powszechna PWN, t. 1, Warszawa 1997, s. 451.

${ }^{7}$ Wielka Encyklopedia PWN, t. 4, Warszawa 2001, s. 12; por. M. Zahajkiewicz, Funkcja i znaczenie biblioteki parafialnej lub klasztornej, ABMK, 77 (2002) s. 9. 
Gdy idzie o określenie biblioteki kościelnej to według J. Szymusiaka w sensie ścisłym są to „biblioteki będące własnością Kościoła katolickiego lub innych chrześcijańskich ugrupowań wyznaniowych" ". Uogólniając definicję biblioteki parafialnej autorstwa W. Śmigla można powiedzieć, że biblioteka kościelna to instytucja gromadzącą, opracowująca i udostępniająca czytelnikom księgozbiór, będąca własnością instytucji kościelnych?

Przede wszystkim biblioteka jest kościelną, kiedy jest własnością Kościoła. Schema-tipo di regolamento delle biblioteche ecclesiastiche italiane Stowarzyszenia Włoskich Bibliotekarzy Kościelnych, zatwierdzony przez Stałą Radę Biskupią Konferencji Episkopatu Włoch na posiedzeniu w dniach 16-19 września 2002 r. zawiera następująca definicję biblioteki kościelnej: „biblioteka kościelna jest to uporządkowany zbiór rękopisów, druków lub opracowań i innych środków, mający na celu przekazywanie tekstów i obrazów, będący w posiadaniu instytucji aprobowanych albo erygowanych w systemie kanonicznym"10.

Biblioteka kościelna jest to uporządkowany zbiór rękopisów, druków lub opracowań i innych środków. Nie chodzi jednak o porządek ustalony przypadkowo; musi on odpowiadać kryteriom rzeczowym i standardom naukowym ${ }^{11}$. Konstytucja Sapientia christiana mówiąc o uniwersytecie lub wydziale kościelnym przypomina, że winna tam znajdować się „odpowiednia biblioteka przystosowana do potrzeb wykładowców i studentów, właściwie uporządkowana i posiadająca dobrze sporządzone katalogi"'12. Na właściwe uporządkowanie materiału bibliotecznego wskazuje pośrednio także inny passus z przywołanej konstytucji apostolskiej, gdzie czytamy: „biblioteka winna stale zwiększać swój księgozbiór (...) tak, by mogła służyć skutecznie pomocą w pracach badawczych poszczególnych dyscyplin, w ich wykładaniu i uczeniu się oraz przy prowadzeniu ćwiczeń i seminariów"13, jak również dyspozycja zawarta w Ratio fundamentalis institutionis sacerdotalis: „narzędziem koniecznym dla pracy naukowej profesorów i studentów jest biblioteka. Alumnów należy naukowo wprowadzić w sposób korzystania

${ }^{8}$ J. Szymusiak, Biblioteki kościelne, w: Encyklopedia Katolicka (dalej EK), red. R. Łukaszyk, t. 2, Lublin 1995, k. 497.

${ }_{9}^{9}$ W. Śmigiel, Biblioteka parafialna, w: Leksykon teologii pastoralnej, red. R. Kamiński, W. Przygoda, M. Fiałkowski, Lublin 2006, s. 97.

${ }^{10}$ Associazione dei Bibliotecari Ecclesiastici Italiani, Schema-tipo di regolamento delle biblioteche ecclesiastiche italiane approvato dalla CEI, art. 1, nr 1, „Bollettino di informazione”, 22 (2002) z. 3, s. 10-19, (dalej: Schema-tipo di regolamento). Biblioteka kościelna należy do dóbr doczesnych Kościoła w myśl kan. 1257 § 1.

${ }^{11}$ Por. Schema-tipo di regolamento, art. 4, nr 6-9.

${ }^{12}$ Ioannes Paulus P.P. II, Constitutio Apostolica Sapientia christiana de Studiorum Universitatibus et Facultatibus ecclesiasticis (29 aprilis 1979), art. 52, „Acta Apostolicae Sedis”, 71 (1979) s. 469-499, (dalej: Sapientia christiana).

${ }^{13}$ Tamże, art. 53. W Uniwersytecie lub Wydziale kościelnym ,powinna być do dyspozycji biblioteka, posiadająca podstawowe dzieła, konieczne do pracy naukowej wykładowców i studentów". Sacra Congregatio pro Institutione Catholica, Ordinationes ad constitutionem apostolicam „Sapientia christiana” rite exequendam (29 aprilis 1979), art. 40, „Acta Apostolicae Sedis”, 71 (1949) s. 500-521. 
z biblioteki"14. Przytoczone zapisy wskazują na konieczność urządzenia zasobów biblioteki według kryteriów rzeczowych i standardów naukowych.

Biblioteka kościelna ma za zadanie przekazywać teksty i obrazy ze swoich materiałów. Okólnik Le biblioteche ecclesiastiche zwraca uwagę, że biblioteki kościelne zachowują, a także udostępniają powstałe na przestrzeni wieków skarby kultury ludzkiej i chrześcijańskiej ${ }^{15}$. Pośrednio o udostępnianiu zasobu bibliotecznego traktuje kan. 824 § 2, gdzie mówi się o książkach i wszelkiego rodzaju pismach przeznaczonych do publicznego rozpowszechniania ${ }^{16}$.

Istotnym elementem definicji biblioteki kościelnej jest to, iż jej właścicielem są określone instytucje kościelne, aprobowane lub erygowane zgodnie z przepisami prawa ${ }^{17}$.

Po określeniu biblioteki kościelnej, należy obecnie wyeksponować różne rodzaje tych bibliotek, tak jak jawią się one w dokumentach prawnych.

W pierwszej kolejności ze względu na poziom organizacji i posiadanych materiałów należy wymienić bibliotekę uniwersytecką, czyli będąca własnością uniwersytetów i wydziałów kościelnych ${ }^{18}$. Constitutio apostolica Sapientia christiana zawiera następujące postanowienie: „dla osiągnięcia właściwych sobie celów, zwłaszcza zaś dla prowadzenia badań naukowych, każdy uniwersytet lub wydział winien mieć odpowiednią bibliotekę, przystosowaną do potrzeb wykładowców i studentów" 19 . Z kolei Ordinationes ad constitutionem apostolicam «Sapientia christiana» rite exequendam uważa bibliotekę, jako jeden koniecznych, najważ-

${ }^{14}$ Sacra Congregazione per L'educazione Cattolica, Ratio fundamentalis institutionis sacerdotalis, (19 marzo 1985), nr 92, editio apparata post Codicem Iuris Canonici promulgatom, Typis Polyglottis Vaticanis 1985.

${ }^{15} \mathrm{Nr}$ 1. 2; por nr 4. 6, 4. 9; por. Pius PP. XII, Adhortatio Apostolica Menti nostrae, pars III; por. Concilium Oecumenicum Vaticanum II, Decretum de Presbyterorum ministerio et vita Presbyterorum Ordinis (7 decembris 1965), nr 19, „Acta Apostolicae Sedis”, 58 (1966) s. 991-1024, tekst polski: Sobór Watykański II, Dekret o postudze i życiu prezbiterów «Presbyterorum ordinis», w: Sobór Watykański II. Konstytucje, dekrety, deklaracje. Tekst polski. Nowe tlumaczenie, Poznań 2002, s. 478-508.

${ }^{16}$ Por. Le biblioteche ecclesiastiche, przypis $\mathrm{nr} 8$.

${ }^{17}$ „Jeśli biblioteki i inne dobra kulturowe należące do Kościoła...”; ,jeśli jednak Kościół, pozostając oczywiście właścicielem odpowiedzialnym za biblioteki, udostępni to dziedzictwo wszystkim, którzy pragną z niego korzystać...”. Le biblioteche ecclesiastiche, nr 4. 9; „Właścicielem i odpowiedzialnym za księgozbiór jest w sensie kanonicznym instytucja albo jednostka, który go posiada”. Schema-tipo di regolamento, art. 4, nr 1. „Zakres formacji kandydatów do kapłaństwa odnosi się nie tylko do sztuki sakralnej (...), ale także do bibliotek, archiwów i muzeów z wyraźną kwalifikacją jako «kościelne», których wiele dziś powstaje, albo są odnawiane i unowocześniane”. Pontificia Commissione per i Beni Culturali della Chiesa, La formazione dei futuri presbiteri all'attenzione verso i beni culturali della Chiesa (Ai vescovi diocesani) (15 ottobre 1992), nr 12, „Notitiae”, 28 (1992) s. 714-731.

${ }^{18}$ Jedyną w swoim rodzaju jest Biblioteka Watykańska (Biblioteca Apostolica Vaticana), czyli centralna biblioteka papieska zlokalizowana w zespole Pałacu Watykańskiego, zawierająca rękopisy i druki, zwłaszcza kościelne. Por. J. Szymusiak, Biblioteka Watykańska, EK, t. 2, red. R. Łukaszyk, Lublin 1995, kol. 496.

${ }^{19}$ Art. 52. 
niejszych warunków dla erekcji nowego niwersytetu lub eydziału kościelnego ${ }^{20}$. Prawodawca domaga się, aby w statutach uniwersytetu lub wydziału zawarte była materia prawna dotycząca „,biblioteki: sposobu jej utrzymania i powiększania”21.

Innym rodzajem bibliotek kościelnych są biblioteki biskupie. Wspomina o nich Lettera circolare Le biblioteche ecclesiastiche, gdzie czytamy: „Komisja (...) zwraca się bezpośrednio do Ordynariuszy diecezji i do Generalnych Przełożonych zgromadzeń zakonnych, aby podzielić się z nimi swoją troską o los wszystkich, starych i nowych bibliotek kościelnych (biskupich, zakonnych, parafialnych, uniwersyteckich itd.)"22, jak również papież Pius PP. XII w adhortatio apostolica Menti nostrae, gdy pisze: ,potrzeba, aby ordynariusze, stosując się do wspaniałej w tym względzie tradycji Kościoła, przywrócili dawną świetność, i żywotność bibliotekom, które kiedyś zakładane były przy katedrach (...)"23.

Wydaje się, że bibliotekę biskupią mają na myśli redaktorzy okólnika Le biblioteche ecclesiastiche, kiedy zachęcają: „,w wielu Kościołach diecezjalnych nadszedł czas na zorganizowanie «jednej wielkiej biblioteki Kościoła lokalnego», która byłaby miejscem w pełni dostępnymi możliwienajlepiej zaopatrzonym w podstawowe dawniejsze i aktualne dzieła myśli chrześcijańskiej. Mogłoby to przywrócić ducha dawnych bibliotek kościelnych w służbie Kościołowi i «Miastu», z których czerpano autentyczne świadectwa o tradycji, i w ten sposób ukazywać przesłanie kultury chrześcijańskiej. Nadto, takie dowartościowanie bibliotek pozostających na służbie Kościoła lokalnego pozwoliłoby na troskliwszą i kompetentniejszą konserwację i ewentualną restaurację książek starych i cennych, która jest trudniejsza, jeśli książki te rozproszone są po różnych małych bibliotekach. Zdajemy sobie oczywiście sprawę z licznych problemów jakie pociąga za sobą ta decyzja, ale wydaje się, że nasze czasy domagają się takiej obecności Kościoła i takiego zaczynu kulturowego w «Mieście»" ${ }^{24}$.

Dalej należy wymienić biblioteki wyższych seminariów duchownych. Seminarium winno mieć własna bibliotekę. „Można erygować i utrzymywać Wyższe Seminarium tylko wtedy, gdy jest (...) stosowny gmach, biblioteka oraz inne urządzenia nieodzowne z racji rangi i charakteru instytucji” ${ }^{25}$; biblioteka jest „,narzędziem koniecznym dla pracy naukowej profesorów i dla studiów alumnów"26.

Jednym ze środków wspomagających kształcenie nauczycieli religii w szkołach publicznych (kursy szkoleniowe) są biblioteki kultury religijnej zawierające określony zbiór książek, adekwatnych w swojej treści do osiągnięcia celu, jakim jest formacja nauczających religii ${ }^{27}$.

${ }^{20}$ Art. $45 \S$ b), nr 3; por. art. 47.

${ }^{21}$ Sacra Congregatio pro Institutione Catholica, Ordinationes ad constitutionem apostolicam „Sapientia christiana" rite exequendam. Appedix I, Normae ad Universitatis vel Facultatis statuta conficienda ad art. 6 Ordinationum (29 aprilis 1979), nr 8, „Acta Apostolicae Sedis”, 71 (1979) s. 500-521; por. Le biblioteche ecclesiastiche, $\mathrm{nr} 3.3$.

${ }^{22} \mathrm{Nr} 3.3$; por. nr 4.1.

${ }^{23}$ Pius PP. XII, Adhortatio Apostolica Menti nostrae, pars III.

${ }^{24} \mathrm{Nr} 4.3$.

${ }^{25}$ Ratio fundamentalis institutionis sacerdotalis, $\mathrm{nr} 21$.

${ }^{26}$ Tamże, nr 92; por. Le biblioteche ecclesiastiche, nr 4. 6. Mówi się też o „bibliotece diecezjalnej". Le biblioteche ecclesiastiche, $\mathrm{nr} 4.5$.

${ }^{27} \mathrm{Na}$ temat tego rodzaju bibliotek istniejących we Włoszech w latach dwudziestych XX wieku, mówi: Sacra Congregatio Concilii, Lettera circolare (28 agosto 1924), w: X. Ochoa, Leges Eccle- 
Papieska Komisja ds. Dóbr Kulturowych postuluje utworzenie „bibliotek misyjnych" w wielu diecezjach, gdzie „plantatio Ecclesiae” datuje się od niedawna i nie jest możliwe stworzenie „bibliotek diecezjalnych”, a nawet „bibliotek narodowych", ponieważ gromadzenie źródeł patrystycznych i znacznych zbiorów teologicznych jest nierealne albo okazuje się bardzo trudne. Aby je stworzyć Kościoły posiadające biblioteki słabo wykorzystywane mogłyby wysyłać publikacje ważne i podstawowe w swej treści (jak np. ważne dzieła filozoficzne i teologiczne, kolekcje źródeł patrystycznych) Kościołom z krajów rozwijających się ${ }^{28}$.

Swoje biblioteki posiadają też kapituły katedralne i kolegiackie. Ordynariusze winni „,przywrócić dawną świetność, i żywotność bibliotekom, które kiedyś zakładane były przy (...) kolegiach kanonicznych"29. Na temat biblioteki kapitulnej mówi także np. Statut Kapituły Kolegiackiej Łaskiej z 2 lutego 2006 r., gdzie znajdujemy zapis: „Do obowiązków Kanonika Kustosza należy (...) odpowiedzialność za archiwum i bibliotekę Kapituły"30. O bibliotece kapitulnej traktuje również inna dyspozycja: „scholastyk wypełnia następujące obowiązki (...) sprawuje opiekę nad archiwum i nad biblioteką Kapituły"31.

Można mówić także o bibliotece muzealnej, której właścicielem jest muzeum diecezjalne, zakonne, parafialne, czy należące do różnych stowarzyszeń. Np. wśród celów Muzeum Diecezjalnego w Drohiczynie jest m. in. ,prowadzenie podręcznej biblioteki z zakresu sztuki kościelnej, muzealnictwa, konserwacji zabytków" ${ }^{32}$. Lettera circolare La funzione pastorale dei musei ecclesiastici sugeruje, aby w strukturze muzeum diecezjalnego znajdowała się specjalistyczna biblioteka. Winna ona zawierać fachowe publikacje i materiały dotyczące dziedzictwa historycznego i artystycznego instytucji właściciela lub promotora muzeum. Biblioteka ta ma za zadanie gromadzić i umożliwiać konsultację przynajmniej publikacji dotyczących historii i kultury lokalnej, często wspieranej i finansowanej przez instytucje kościelne, władze lokalne i osoby prywatne ${ }^{33}$.

Często swoje biblioteki posiadają różne sanktuaria. Np. dekret ustanawiający

siae post Codicem iuris canonici editae, vol. I, Roma 1966, col. 715. Trzeba dodać, że dokument ten jest jednym ze źródeł kan. 775 KPK z 1983 r. Zob. Pontificia Commissio Codici Iuris Canonici Authentice Interpretando, Codex Iuris Canonici Auctoritate Ioannis Pauli PP. II promulgatus. Fontium annotatione et indice analitico-alphabetico auctus, Libreria Editrice Vaticana 1989, przypis do kan. 775.

${ }^{28}$ Por. Le biblioteche ecclesiastiche, $\mathrm{nr} 4.8$.

${ }^{29}$ Pius PP. XII, Adhortatio Apostolica Menti nostrae, pars III.

${ }^{30}$ Statut Kapituły Kolegiackiej Łaskiej (2 lutego 2006), art. 12 b, „,Wiadomości Archidiecezjalne Łódzkie", 80 (2006) nr 4, s. 265.

${ }^{31}$ Statuty Kolegiackiej Kapituły Krypniańskiej (8 maja 1997), nr 17 c, „Wiadomości Kościelne Archidiecezji w Białymstoku”, 25 (1997) nr 2, s. 51.

32 Statut Muzeum Diecezjalnego w Drohiczynie (3 marca 2005), nr 18, „Komunikaty Kurii Diecezjalnej w Drohiczynie n. Bugiem”, 18 (2005) nr 2, s. 45; Statut Muzeum Diecezjalnego, § 6, nr 7, w: Pierwszy Synod Diecezji Zamojsko-Lubaczowskiej 1996-2001, Zamość 2001, s. 205.

${ }^{33}$ Pontificia Commissione per i Beni Culturali della Chiesa, Lettera circolare La funzione pastorale dei musei ecclesiastici (29 iunii 2001), nr 3.1.8, w: Enchiriděon dei Beni Culturali della Chiesa. Documenti ufficiali della Pontificia Commissione per i Beni Culturali della Chiesa, Edizioni Dehoniane, Bologna 2002, s. 464-526. 
sanktuarium MB Fatimskiej w Braniewie z 4 kwietnia 1998 r., zawiera postanowienie: „Sanktuarium prowadzi Archiwum z Aktami, Ilustrowaną Kroniką, Księgą Łask i Wotów, Księgą Pielgrzymek, nadto Bibliotekę i Muzeum Fatimskie"34.

II Polski Synod Plenarny poleca „tworzenie ośrodków życia uczelnianego z kościołem akademickim, biblioteką "35.

Istotne miejsce w przeprowadzanej klasyfikacji zajmują biblioteki parafialne. „Ważne jest, by nie lekceważyć bibliotek o mniejszym znaczeniu - parafialnych (...), które często w przeszłości, jako «ośrodki świetlicowe» odgrywały ważną rolę w społecznościach wiejskich, gdzie nie łatwy był dostęp do wielkich źródeł kultury (...) Zdaje się, że centrum diecezjalne skutecznie działające oraz inspirowane przez personel zajmujący się sprawami dóbr kultury, jak - biblioteka, archiwa i dzieła sztuki, powinno umiejętnie angażować się w podtrzymywaniu i przekształcaniu bibliotek należących do parafii $(\ldots)^{36}$.

W strukturze parafii, ale i kurii diecezjalnej mogą być także biblioteki specjalistyczne. Taką biblioteką jest $\mathrm{m}$. in. biblioteka poradni życia rodzinnego. W tej sprawie Dyrektorium duszpasterstwa rodzin zawiera następującą dyspozycję: „,W poradni powinny znajdować się materiały poglądowe, potrzebne do pracy doradcy, oraz odpowiednio wyposażona biblioteka"37. Do tego typu bibliotek należy także parafialna biblioteka muzyczna ${ }^{38}$.

Także w kancelarii parafialnej istnieją niewielkie biblioteki. Na ten temat znajdujemy dyspozycję kanoniczną w przepisach I Synodu Diecezji Ełckiej, gdzie czytamy: „zaleca się, aby w biurze parafialnym znajdowały się jeszcze: podręczna biblioteczka, a w niej Pismo Święte, dokumenty Soboru Watykańskiego II, Kodeks Prawa Kanonicznego, Statuty Synodu Plenarnego, Statuty Synodu Diecezjalnego, Katechizm Kościoła Powszechnego, poszczególne i kompletne roczniki Kroniki Urzędowej Diecezji Ełckiej, komunikaty władzy diecezjalnej oraz listy pasterskie Biskupa Ełckiego, a także podręczniki ważniejszych dyscyplin kościelnych" ${ }^{\prime 3}$.

Następne w systematyzacji bibliotek, to księgozbiory zakonne (klasztorne). Autorzy listu okólnego Biblioteki kościelne w misji Kościoła wzywają przełożonych zgromadzeń zakonnych, aby troszczyli się o los wszystkich, starych i nowych bibliotek zakonnych ${ }^{40}$.

${ }^{34}$ Dekret ustanawiajacy sanktuarium MB Fatimskiej w Braniewie (4 kwietnia 1998), § 7, „Warmińskie Wiadomości Archidiecezjalne", 53 (1998) nr 36, s. 33; por. kan. 1234 § 1.

${ }^{35}$ II Polski Synod Plenarny (1991-1999), Poznań 2001, st. 75, s. 61.

${ }^{36}$ Le biblioteche ecclesiastiche, $\mathrm{nr} 4$. 4; por. $\mathrm{nr} 4$. 5; 4. 9; por. Congregatio pro Episcopis, Direttorio per il ministero pastorale dei vescovi (22 febbraio 2004), $\mathrm{nr} 212$, Cittŕ del Vaticano 2004, tekst polski: Kongregacja do spraw Biskupów, Dyrektorium o pasterskiej postudze biskupów „Apostolorum Successores" (22 lutego 2004), Kielce 2005. Okólnik Biblioteki kościelne w misji Kościoła mówi także o bibliotekach regionalnych. $\mathrm{Nr} 4.5$.

${ }^{37}$ Dyrektorium duszpasterstwa rodzin (1 maja 2003), nr 41, „Miesięcznik Archidiecezji Gdańskiej”, 48 (2004) nr 7-9, s. 436-486; por. nr 42; por. I Synod Diecezji Ełckiej 1997-1999, Ełk 1999, st. 233, s. 51; por. I Synod diecezji Koszalińsko-Kołobrzeskiej 1986-1990, Koszalin 1990, st. 58, s. 12.

${ }^{38}$ Por. Pierwszy Synod Diecezji Zamojsko-Lubaczowskiej, st. 38, s. 38.

${ }^{39}$ I Synod Diecezji Etckiej, st. 369, s. 66.

${ }^{40}$ Por. Le biblioteche ecclesiastiche, nr 3. 3; por. nr 4. 1; 4. 2; zob. Szymusiak Biblioteki kościelne, k. 500. 
Wreszcie istnieją biblioteki kościelne należących do różnych stowarzyszeń ${ }^{41}$ i organizacji ${ }^{42}$.

\section{Zbiory biblioteczne}

Według Schema-tipo di regolamento delle biblioteche ecclesiastiche italiane „biblioteka kościelna jest to uporządkowany zbiór rękopisów, druków lub opracowań i innych środków (...)"³. Biblioteka to przede wszystkim materiały biblioteczne.

Gdy idzie o rodzaj tych materiałów Z. Gaca-Dąbrowska zaznacza, że w skład zbiorów wchodzą przede wszystkim dokumenty tekstowe, takie jak: książki, czasopisma, rękopisy, druki ulotne, normy, patenty, literatura firmowa. Ponadto na zbiory składają się zapisy dźwięku i druki - a więc nuty, płyty, taśmy dźwiękowe, afisze, ryciny, mapy, plany, globusy itd." ${ }^{44}$. Biblioteki kościelne w różnej mierze zawierają podobne rodzaje zasobów. Tak zatem posiadają książki ${ }^{45}$, czasopisma ${ }^{46}$, pergaminy ${ }^{47}$, manuskrypty ${ }^{48}$, „inne nośniki informacji” ${ }^{49}$, czy „inne środki przekazu kultury" $"$.

$\mathrm{W}$ aspekcie treści ${ }^{51}$, kościelne zbiory biblioteczne zawierają pozycje z dziedziny teologii ${ }^{52}$, biblistyki ${ }^{53}$, prawa kanonicznego ${ }^{54}$, filozofii ${ }^{55}$. Zbiory zawierają „klasyków greckich i łacińskich, dokumenty poświęcone różnym kulturom i religiom, zabytki historii oraz sztuki przeróżnych ludów i cywilizacji" ${ }^{\prime 56}$, źródła patrystyczne ${ }^{57}$, „zbiory dekretów albo aktów, wydane przez jakąś władzę kościelną"58, jak również „dokumenty i świadectwa, które dotyczą duszpasterstwa, praw i obo-

${ }^{41}$ „Ważne jest, by nie lekceważyć bibliotek o mniejszym znaczeniu (...) należących do różnych stowarzyszeń". Le biblioteche ecclesiastiche, $\mathrm{nr}$ 4. 4.

${ }^{42}$ Tamże, nr 4. 9.

${ }^{43}$ Schema-tipo di regolamento, art. $1, \mathrm{nr} 1$.

${ }^{44}$ Wielka Encyklopedia PWN, t. 4, Warszawa 2001, s. 12.

${ }^{45}$ Sapientia christiana, art. 53; Le biblioteche ecclesiastiche, nr 4. 4; 4. 5.

${ }^{46}$ Sapientia christiana, art. 53; Schema-tipo di regolamento, art. 33, nr 1; Pierwszy Synod Diecezji Zamojsko-Lubaczowskiej, st. 135, s. 107; Synod Archidiecezji Wrocławskiej 1985-1991, Wrocław 1995, st. 35, s. 267.

${ }^{47}$ Pius PP. XII, Adhortatio Apostolica Menti nostrae, pars III; zob. Zahajkiewicz, Funkcja i znaczenie biblioteki parafialnej, s. 16

${ }^{48}$ Schema-tipo di regolamento, art. 1, nr 1; art. 33, nr 1; Pius PP. XII, Adhortatio Apostolica Menti nostrae, pars III.

${ }^{49}$ Le biblioteche ecclesiastiche, $\mathrm{nr} 4.4$.

${ }^{50}$ Tamże, nr 4. 4.

${ }^{51}$ Zob. Zahajkiewicz, Funkcja i znaczenie biblioteki parafialnej, s. 15.

${ }^{52}$ Le biblioteche ecclesiastiche, nr 4. 6; por. kan. 252 § 1; por. Leszczyński, Biblioteki kościelne, s. 33.

${ }^{53}$ Por. kan. $252 \S 2$.

${ }^{54}$ Por. kan. $827 \S 2$; por. kan. $253 \S 2$.

${ }^{55}$ Le biblioteche ecclesiastiche, $\mathrm{nr} 4$. 6; por. kan. 251.

${ }^{56}$ Le biblioteche ecclesiastiche, $\mathrm{nr} 2.2$.

${ }^{57}$ Tamże, nr 4. 8.

${ }^{58}$ Por. kan. 828. 
wiązków diecezji, parafii, kościołów oraz osób prawnych założonych w Kościele" ${ }^{\prime 59}$ oraz ,dzieła traktujące na tematy (...) społeczne" ${ }^{\prime 60}$, a także prace badawcze ${ }^{61}$, czy prasę katolicką ${ }^{62}$. Dyspozycja według której „każdy Uniwersytet lub Wydział winien mieć odpowiednią bibliotekę, przystosowana do potrzeb wykładowców i studentów"63 pośrednio wskazuje na charakter księgozbioru bibliotek kościelnych, które winny zawierać pozycje z wymienionych dziedzin nauki ${ }^{64}$.

Jeśli chodzi o wielkość księgozbioru to można rozróżnić biblioteki wielkie ${ }^{65}$, o średniej ilości pozycji bibliotecznych ${ }^{66}$, małe (biblioteki „o mniejszym znaczeniu - parafialne lub należące do różnych stowarzyszeń”) ${ }^{67}$, czy bardzo małe (,biblioteczki" $\left.{ }^{68}\right)$.

Zadaniem każdej biblioteki, także kościelnej, jest przede wszystkim utrzymanie księgozbioru ${ }^{69}$, jego konserwacja i restauracja ${ }^{70}$.

Biblioteka winna także systematycznie, w miarę możliwości powiększać i aktualizować, zgodnie z potrzebami wykładowców i studentów, swój księgozbiór. Prawodawcy wielokrotnie wypowiadają się w tej sprawie. Okólnik Le biblioteche ecclesiastiche przypomina, ze ,jest rzeczą konieczną, aby każda diecezja i każde zgromadzenie zakonne starało się (...) regularne powiększanie zbiorów"71, a adhortacja apostolska Menti nostrae precyzuje: „trzeba biblioteki kościelne przystosować do potrzeb naszych czasów, zaopatrując je w dzieła różnego rodzaju, mając głównie na względzie dzieła traktujące na tematy religijne i społeczne, a kierując się tym, aby profesorowie, proboszczowie i szczególnie młodzi kapłani mogli z nich dostatecznie naukowo korzystać"72. Wyraźnie powiększanie zbioru nakazuje Ratio fundamentalis institutionis sacerdotalis w słowach: „Przy pomocy zainteresowanych osób stale winna być ona [biblioteka] powiększana dzięki corocznemu przeznaczeniu na ten cel wystarczającej sumy pieniędzy"73.

${ }^{59}$ Ioannes Paulus P.P. II, Constitutio Apostolica Pastor Bonus, (28 iulii 1988), art. 101, „Acta Apostolicae Sedis", 80 (1988) s. 841-912, (odtąd: PB).

${ }^{60}$ Pius PP. XII, Adhortatio Apostolica Menti nostrae, pars III.

${ }^{61}$ Schema-tipo di regolamento, art. 33, nr 1.

${ }^{62}$ Por. Drugi Synod Diecezji Włocławskiej. Statuty. Włocławek 1994, st. 457, s. 127.

${ }^{63}$ Sapientia christiana, art. 52.

${ }^{64}$ Podobny wydźwięk ma także dyspozycja: ,katalog ogólny biblioteki może być z pożytkiem uzupełniany przez katalogi ułożone według zagadnień lub szczegółowych tematów”. Schema-tipo di regolamento, art. 8 .

${ }^{65}$ Por. Le biblioteche ecclesiastiche, nr 4. 3; por. Sapientia christiana, art. 52.

${ }^{66} \mathrm{~Np}$. biblioteka seminarium duchownego. Por. Ratio fundamentalis institutionis sacerdotalis, nr 21; 92 .

${ }^{67}$ Le biblioteche ecclesiastiche, $\mathrm{nr}$ 4. 4.

${ }^{68}$ I Synod Diecezji Ełckiej, st. 369, s. 66.

${ }^{69}$ Por. Le biblioteche ecclesiastiche, $\mathrm{nr} 4$. 9; por. Ratio fundamentalis institutionis sacerdotalis, nr 92.

${ }^{70}$ Por. Le biblioteche ecclesiastiche, $\mathrm{nr} 4$ 4. 3; por. PB, art. 100-101.

${ }^{71}$ Le biblioteche ecclesiastiche, $\mathrm{nr}$ 4. 1; por. $\mathrm{nr}$ 4. 9.

72 Pius PP. XII, Adhortatio Apostolica Menti nostrae, pars III.

${ }^{73} \mathrm{Nr}$ 92; por. Sacra Congregatio pro Institutione Catholica, Ordinationes ad constitutionem apostolicam ,Sapientia christiana” rite exequendam. Appedix I, Normae ad Universitatis vel Fa- 
Biblioteka pomnaża własny księgozbiór poprzez nabywanie, darowizny, wymianę, zapisy ${ }^{74}$. Nabywanie jest możliwe dzięki subwencjom, o których w Ratio fundamentalis institutionis sacerdotalis czytamy: „narzędziem koniecznym dla pracy naukowej profesorów i dla studiów alumnów jest biblioteka. (...) winna być ona powiększana dzięki corocznemu przeznaczeniu na ten cel wystarczającej sumy pieniędzy" "75. Podobnie mówi konstytucja Sapientia Christiana: ,przez odpowiednia sumę pieniędzy, przyznawane każdego roku, biblioteka winna stale powiększać swój księgozbiór, zarówno dawnymi jak i współcześnie wydanymi pozycjami, a także podstawowymi czasopismami - tak by mogła służyć skutecznie pomoce w pracach badawczych poszczególnych dyscyplin, w ich wykładaniui uczeniu się oraz przy prowadzeniu ćwiczeń i seminariów" "76.

Redaktorzy Schema-tipo di regolamento zachęcają, aby stowarzyszenia świeckie, ruchy, grupy nieformalne i wierni, którzy wykonują szczególne zadania w Kościele nie rozpraszali własnego zasobu książek, rozporządzając, aby we właściwym czasie spłynął on do biblioteki diecezjalnej czy do biblioteki kościelnej, która będzie go szanować i w miarę możności utrzymywać jego integralność ${ }^{77}$. W tej kwestii IV Synod Archidiecezji Warszawskiej zamieszczając wzór testamentu kapłana sugeruje: ,albumy i książki przeznaczam dla Biblioteki Seminaryjnej" 78 .

Ważną misją bibliotek kościelnych (tych większych i prężniejszych) jest także zachowanie każdego zbioru książek, z bibliotek mniejszych, który to zbiór może być rozproszony lub utracony z powodu pewnych obiektywnych przyczyn ${ }^{79}$. Stąd „nie należy godzić się z nieuchronnością tego procesu, lecz trzeba uczynić wszystko, aby zachować każdy zbiór książek, nie rzadko bardzo cenny, należący do parafii lub do stowarzyszenia, które przestało istnieć, albo też przekształcać w biblioteki regionalne względnie diecezjalne, gromadząc pozbawione pieczy i niewykorzystywane zbiory w jednym centrum, by dalej mogły z pożytkiem służyć czytelnikom" $"$.

Zadaniem biblioteki kościelnej jest także udostępnianie zbiorów badaczom i czytelnikom. Biblioteka bowiem nie jest zwykłą przechowalnią książek, lecz udostępnia ,powstałe na przestrzeni wieków skarby kultury ludzkiej i chrześcijańskiej” ${ }^{\text {, }}$ jest to „uporządkowany zbiór rękopisów, druków lub opracowań i in-

cultatis statuta conficienda ad art. 6 Ordinationum, $\mathrm{nr} 8$.

${ }^{74}$ Por. Schema-tipo di regolamento, art. 3.

${ }^{75} \mathrm{Nr} 92$.

${ }^{76}$ Art. 53.

${ }^{77}$ Art. 5, nr 2.

${ }^{78}$ IV Synod Archidiecezji Warszawskiej, Warszawa 2003, Zapisy testamentowe b), s. 118.

${ }^{79}$ „Nie można zapomnieć o czynniku tak znamiennym dla wielu krajów: zmniejszenie się liczby księży, którzy, co było oczywiste, zajmowali się tworzeniem i prowadzeniem bibliotek parafialnych i należących do różnych stowarzyszeń, pociąga to za sobą spadek ilości i aktywności tychże bibliotek". Le biblioteche ecclesiastiche, nr 4. 5.

${ }^{80}$ Le biblioteche ecclesiastiche, $\mathrm{nr} 4.5$.

${ }^{81}$ Tamże, nr 1. 2. 
nych środków, mający na celu przekazywanie tekstów i obrazów" ${ }^{2}$. O tym zadaniu księgozbiorów kościelnych wielokrotnie wypowiadają się dokumenty kościelne. Warto przywołać charakterystyczne dyspozycje: „każdy Uniwersytet lub Wydział winien mieć odpowiednią bibliotekę, przystosowana do potrzeb wykładowców i studentów” "83; „narzędziem koniecznym dla pracy naukowej profesorów i dla studiów alumnów jest biblioteka. W każdym Seminarium winien ja prowadzić $\mathrm{z}$ wielka starannością. (...) Alumnów należy naukowo wprowadzić w sposób korzystania z biblioteki” " zaś martwym składem książek, trzeba w nich przeznaczyć odpowiednie sale na lekturę dzieł i na studia. Przede wszystkim zaś trzeba te biblioteki, przystosować do potrzeb naszych czasów, (...) aby profesorowie, proboszczowie i szczególnie młodzi kapłani mogli z nich dostatecznie naukowo korzystać dla rozkrzewienia prawdy ewangelicznej i dla zwalczania błędów"85.

Korzystaniezbiblioteki poleganawypożyczaniuimożliwości korzystaniazczytelni zgodnie z przepisami prawa ${ }^{86}$. Odnośnie czytelni Pius XII przypomina: „aby biblioteki kościelne były żywym organizmem, nie zaś martwym składem książek,

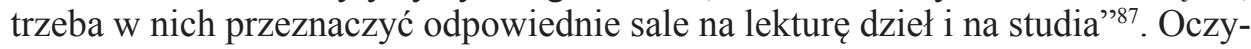
wiście możliwość wypożyczania pozycji bibliotecznych jest zawsze mniejsza od możliwości korzystania z tych dzieł „na miejscu”, w czytelni, a to ze względu na to, że wielu dzieł (wymienionych w regulaminach i statutach) z różnych powodów, które są najczęściej uwzględnione w statutach lub regulaminach nie udostępnia się poza określonymi miejscami w siedzibie biblioteki. Schema-tipo di regolamento zawiera w tej materii następujące postanowienia: „biblioteka może zezwalać na wypożyczanie materiału bibliograficznego, wyłączając rękopisy, zasadniczo stare książki, materiały nawet współczesne, ale rzadko występujące i wartościowe, prace badawcze, periodyki i materiał archiwalny" ${ }^{\prime 8}$.

\section{Organizacja bibliotek kościelnych}

Z. Gaca-Dąbrowska definiuje bibliotekę jako „instytucję, która pełni określone funkcje społeczne (np. badawcze, edukacyjne, kulturalne itd.) przez planowe gromadzenie, opracowanie i udostępnianie zbiorów oraz informowanie o nich" ${ }^{\prime \prime}$. Biblioteka kościelna to nie tylko księgozbiór, ale instytucja, która planowo gromadzi, opracowuje i udostępnia zbiory oraz informuje o nich. Jest więc zrozumia-

${ }^{82}$ Schema-tipo di regolamento, art. 1.1.

${ }^{83}$ Sapientia christiana, art. 52.

${ }^{84}$ Ratio fundamentalis institutionis sacerdotalis, $\mathrm{nr} 92$.

${ }^{85}$ Pius PP. XII, Adhortatio Apostolica Menti nostrae, pars III.

${ }^{86}$ Por. Schema-tipo di regolamento, art. 33.

${ }^{87}$ Adhortatio Apostolica Menti nostrae, pars III. „Jeśli jednak Kościół, pozostając oczywiście właścicielem odpowiedzialnym za biblioteki, udostępni to dziedzictwo wszystkim, którzy pragną z niego korzystać, wydaje się słuszne, by zostały one zaliczone do bogactwa kulturowego całego kraju". Le biblioteche ecclesiastiche, nr 4. 9.

${ }^{88}$ Art. 33, nr 1.

${ }^{89}$ Wielka Encyklopedia PWN, t. 4, Warszawa 2001, s. 12; por. Zahajkiewicz, Funkcja i znaczenie biblioteki parafialnej, s. 9. 
łe, że biblioteka musi posiadać właściwą sobie organizację. Na konieczność organizacji wielokrotnie wskazują prawodawcy. Okólnik Le biblioteche ecclesiastiche zawiera zapis odnoszący się do tej kwestii: ,jest rzeczą konieczną, aby każda diecezja i każde zgromadzenie zakonne starało się, jeśli nie jest to jeszcze wykonane, sporządzić stosowny inwentarz i określić charakter swych bibliotek, by umożliwić zaplanowanie poczynań dotyczących przestrzeni niezbędnej zarówno dla użytkowników, jak i dla posiadanych zasobów, nie mówiąc już o planowaniu regularnego powiększania zbiorów, zakupie sprzętu potrzebnego do obsługi, i finansowaniu projektów"90. Podobnie czyni Konstytucja Jana Pawła II Sapientia Christiana: „dla osiągnięcia właściwych sobie celów, zwłaszcza zaś dla prowadzenia badań naukowych, każdy Uniwersytet lub Wydział winien mieć odpowiednią bibliotekę, przystosowaną do potrzeb wykładowców i studentów, właściwie uporządkowana i posiadające dobrze sporządzone katalogi"’1.

W ramach organizacji biblioteki zasadniczą sprawą są dobrze sporządzone katalogi. „Dla osiągnięcia właściwych sobie celów, zwłaszcza zaś dla prowadzenia badań naukowych, każdy Uniwersytet lub Wydział winien mieć odpowiednią bibliotekę (...) posiadające dobrze sporządzone katalogi" "92. Schema-tipo di regolamento zawiera w tej kwestii następujący zapis: „teksty przechowywane w bibliotece muszą być skatalogowane według kryterium, które ułatwi ich odszukiwanie i będzie sprzyjać wymianie informacji bibliograficznej z innymi bibliotekami, przede wszystkim z kościelnymi”"93. „Katalogi winny być stale aktualizowane w ten sposób, aby ułatwić zarządzanie materiałem bibliotecznym i poszukiwania"94. Według ważnego zalecenia Schema-tipo di regolamento ,duplikat katalogów bibliotek podległych jurysdykcji biskupa winien być przechowywany w bibliotece diecezjalnej lub przy diecezjalnym urzędzie dla dóbr kulturalnych"95.

Z katalogami ściśle łączy się komputeryzacja bibliotek: katalogi komputerowe, wewnętrzna sieć komputerowa w bibliotece oraz włączenie biblioteki do krajowych i międzynarodowych sieci komputerowych. List okólny Biblioteki kościelne w misji Kościoła zawiera w tym względzie ważne uwagi: ,dziś, kiedy odległości już nie są problemem, a komputeryzacja pozwala z całą łatwością na wzajemną pomoc i wymianę, można poważniej myśleć o planowym tworzeniu bibliotek, by podnieść ich poziom i zwiększyć dostępność"96 , jak również „współpraca ta stanie się sprawniejsza, jeśli biblioteki kościelne będą uczestniczyć, za pośrednictwem krajowych sieci komputerowych, w wymianie informacji bibliograficznych z innymi bibliotekami kościelnymi i państwowymi" ${ }^{\prime 7}$.

Ważnym aspektem organizacyjnym biblioteki kościelnej jest właściwie upo-

\footnotetext{
${ }^{90} \mathrm{Nr} 4.1$.

${ }^{91}$ Art. 52.

${ }^{92}$ Sapientia christiana, art. 52; por. Le biblioteche ecclesiastiche, $\mathrm{nr} 1.4$.

${ }^{93}$ Art. 6.

${ }^{94}$ Schema-tipo di regolamento, art. 7. „Katalog ogólny biblioteki może być z pożytkiem uzupełniany przez katalogi ułożone według zagadnień lub szczegółowych tematów". Tamże, art. 8.

${ }^{95}$ Art. 8, nr 2.

${ }^{96} \mathrm{Nr} 4.1$.

${ }^{97} \mathrm{Nr} 1.4$.
} 
rządkowana sprawa korzystania z czytelni i wypożyczalni. Kwestie te są szczegółowo regulowane $\mathrm{w}$ statutach i regulaminach bibliotek zatwierdzonych przez kompetentną władzę kościelną. Np. Schema-tipo di regolamento w wielu miejscach mówi o czytelni: „W pomieszczeniach biblioteki winny być czytelnie ${ }^{98}$. Czytelnia musi być sumiennie nadzorowana" ${ }^{\circ 9}$. W czytelni i w pomieszczeniach przyległych winna panować cisza, czytelnicy powinni zachowywać się zgodne $\mathrm{z}$ naturą tych miejsc i być odpowiednio ubrani ${ }^{100}$. „W salach bibliotecznych jest wzbronione palenie i spożywanie posiłków oraz napojów"101. Przed wejściem do czytelni użytkownicy składają w specjalnej szatni płaszcze, palta, kurtki, torby, parasole i inne duże przedmioty ${ }^{102}$.

Odpowiedzialni za biblioteki kościelne winni być otwarci także na kwestie prezentowania i instruowania $\mathrm{w}$ sprawach księgozbiorów kościelnych i korzystania $\mathrm{z}$ nich. Instrukcja La formazione dei futuri presbiteri all'attenzione verso i beni culturali della Chiesa, proponuje, by w trakcie formacji kapłańskiej przewidzieć możliwość odwiedzania przez alumnów instytucji diecezjalnych, zajmującymi się kościelnymi dobrami kultury, takimi jak muzea diecezjalne, archiwa, biblioteki ${ }^{103}$.

Czasami korzystanie z konkretnych materiałów może wiązać się ze spełnieniem określonych warunków, które są często precyzowane w regulaminach, czy statutach biblioteki. Np. Schema-tipo di regolamento reguluje kwestię konsultacji manuskryptów lub starodruków. W takich przypadkach lektura tych materiałów jest zastrzeżona dla tych, który osiągnęli pełnoletniość. Dalej, konsultacja może być przedmiotem kolejnych szczególnych ograniczeń, takich, jak na przykład, weryfikacja faktycznych kwalifikacji petenta do thumaczenia lub odczytania treści materiałów, okazanie pisemnej prezentacji czytelnika sporządzonej przez jego nauczyciela w przypadku studentów, którzy prowadzą szczegółowe badania, złożenie dowodu tożsamości podczas pobytu w czytelni ${ }^{104}$.

Biblioteki pod pewnymi warunkami mogą umożliwiać, na żądanie czytelników i badaczy, reprodukcje swoich zasobów. Np. Schema-tipo di regolamento zawiera $\mathrm{w}$ tej kwestii następującą dyspozycję: ,po przedstawieniu odpowiedniego podania i w poszanowaniu obowiązujących norm, dyrekcja może zezwolić na uzyskanie fotokopii części woluminów, z wykluczeniem manuskryptów, druków starych i drogocennych, albo mogących łatwo ulec zniszczeniu"105.

Prawo wewnętrzne bibliotek kościelnych reguluje także sprawę wypożyczania materiałów poza siedzibę biblioteki. Zawsze obowiązuje generalna zasada, w myśl której „w żadnym wypadku nie można wynosić materiałów poza bibliote-

${ }^{98}$ Zob. Le biblioteche ecclesiastiche, nr 4. 1; zob. Pius PP. XII, Adhortatio Apostolica Menti nostrae, pars III.

${ }^{99}$ Art. 21.

${ }^{100}$ Por. Schema-tipo di regolamento, art. 29, nr 1.

${ }^{101}$ Tamże.

${ }^{102}$ Por. tamże.

${ }^{103} \mathrm{Nr} 24$; por. nr 26; por. Ratio fundamentalis institutionis sacerdotalis, nr 92.

${ }^{104}$ Por. Schema-tipo di regolamento, art. 24.

${ }^{105}$ Art. 30, nr 1. 
kę, z wyjątkiem wypożyczenia, kiedy takie jest przewidziane"106. Gdy jest możliwość wypożyczania, proszący musi spełnić konkretne warunki, które ustala zarząd biblioteki oraz przestrzegać określonego czasu trwania pożyczki. Ewentualne opóźnienia w oddaniu pozycji mogą spowodować proporcjonalne kary pieniężne, a w przypadkach większych obciążeń, wykluczenie z korzystania z usług biblioteki ${ }^{107}$.

Natomiast wypożyczanie materiałów od czasu do czasu dla zorganizowania ekspozycji i wystaw powinno być umożliwione po pilnym sprawdzeniu stanu zakonserwowania materiału. Należy także żądać gwarancji bezpieczeństwa podczas transportu i w siedzibie wystawy oraz odpowiedniego ubezpieczenia. Trzeba przy tym respektować obowiązujące normy kanoniczne i cywilne w tej materii ${ }^{108}$.

W organizacji pracy biblioteki istotną rzeczą jest czas pracy biblioteki i jej otwarcia dla korzystających z niej ${ }^{109}$.

Biblioteki kościelne winny być także odpowiednio wyposażone w różne urządzenia techniczne, ułatwiające opracowywanie księgozbioru i korzystanie z niego. Konstytucja Sapientia Christiana postanawia, że „Wydział (także biblioteka na Wydziale - J. A.) winien mieć do dyspozycji również urządzenia techniczne, audiowizualne itd., stanowiące pomoc w pracy dydaktycznej" ${ }^{110}$. Natomiast List okólny Biblioteki kościelne w misji Kościoła przypomina, że ,jest rzeczą konieczną, aby każda diecezja i każde zgromadzenie zakonne starało się (...) o zakup sprzętu potrzebnego do obsługi" "l11. Powinno się dążyć do komputeryzacji bibliotek $^{112}$, a także zapewnić im nowoczesne nośniki informacji ${ }^{113}$.

Oprócz koniecznego wyposażenia biblioteki, doniosłe znaczenie ma także odpowiednia ochrona i zabezpieczenie zbiorów i pomieszczeń bibliotecznych. Schema-tipo di regolamento zawiera w tej kwestii następującą dyrektywy: w bibliotekach „wykonuje się okresowo odkurzanie, dezynfekcję i odkażanie pomieszczeń biblioteki, z wykorzystaniem wyspecjalizowanego personelu" ${ }^{114}$; „,biblioteka z odnośnym zasobem bibliograficznym i dokumentalnym, powinna być chroniona za pomocą systemów bezpieczeństwa i ochrony przeciwpożarowej, instalacje elektrycznej muszą być zgodne z obowiązującymi normami bezpieczeństwa. Jeśli jest konieczne, muszą być zainstalowane urządzenia do regulacji temperatury i wilgoci" 115 .

Biblioteki kościelne winny również współpracować z innymi tego typu insty-

\footnotetext{
${ }^{106}$ Tamże, art. 28, nr 1.

${ }^{107}$ Tamże, art. 33, nr 1.

${ }^{108}$ Por. tamże, art. 33, nr 2; zob. Le biblioteche ecclesiastiche, $\mathrm{nr} 4.7$.

${ }^{109}$ Por. Schema-tipo di regolamento, art. 2, $\mathrm{nr} 2$.

${ }^{110}$ Art. $55 \S 1$.

${ }^{111} \mathrm{Nr} 4.1$.

${ }^{112}$ Zob. Le biblioteche ecclesiastiche, $\mathrm{nr}$ 4. 1.

${ }^{113}$ Por. tamże, nr 4. 4.

${ }^{114}$ Art. 15, nr 1.

${ }^{115}$ Por. Schema-tipo di regolamento, art. 13, nr 1-2.
} 
tucjami, zarówno kościelnymi ${ }^{116}$ jak i nie będącymi własnością kościelnych osób prawnych $^{117}$.

W celu wzajemnej pomocy i koordynacji działalności bibliotek kościelnych ważne jest tworzenie i ,umacnianie federacji bibliotek kościelnych w różnych krajach, by mogły one, jednocząc się, pomagać sobie wzajemnie w swoich problemach i zapewnić okresowe szkolenia swoim pracownikom"118.

Ponieważ biblioteka kościelna jest ,żywym organizmem (instytucją J.A), nie zaś martwym składem książek” 119 i winna być „właściwie uporządkowana”120, nieodzowny jest istnienie odpowiedniego personelu.

Autorzy okólnika Le biblioteche ecclesiastiche przypominają, że „podobnie jak w innych dziedzinach duszpasterzowania, poszukuje się coraz bardziej wykwalifikowanych pracowników. To samo musi mieć miejsce w sektorze bibliotek"121.

Przede wszystkim na czele biblioteki winien stać dyrektor (nazywany bibliotekarzem) ${ }^{122}$ mianowany przez kompetentną władzę kościelną. „Do kierowania biblioteką winna być wyznaczona biegła w tej materii osoba, wspomagana przez odpowiednie Radę i uczestnicząca w Radach Uniwersytetu lub Wydziału" ${ }^{23}$, „zgodnie z miejscowym zwyczajem w każdym Seminarium winni być ludzie odpowiedzialni za kierowanie nim. Są to: Rektor, Wicerektor, Ojciec lub Ojcowie duchowni, Prefekt studiów, Kierownik praktyk duszpasterskich, Prefekt porządku życia wspólnego Seminarium, ekonom, bibliotekarz. Jasno powinny być określone ich funkcje, prawa i obowiązki oraz słuszne wynagrodzenie" ${ }^{24}$. Jednakże w „seminarium o bardziej skromnych warunkach, obejmujących mniejsza liczbę alumnów, nie jest ściśle wymagane, aby do wyszczególnionych tu funkcji było przydzielonych tylu ludzi" ${ }^{125}$, stąd bibliotekarz może pełnić w takich przypadkach inne urzędy, lub ktoś z pracowników seminarium może być jednocześnie bibliotekarzem.

Wspomniany bibliotekarz winien być nie tylko zatrudnionym pracownikiem,

116 „Należy dążyć do zainicjowania stałego i wnikliwego dialogu między osobami odpowiedzialnymi za biblioteki kościelne w danym kraju”. Le biblioteche ecclesiastiche, nr 4. 4; por. nr 4. 2.

117 „Należy dążyć do zainicjowania stałego i wnikliwego dialogu między osobami odpowiedzialnymi za biblioteki kościelne w danym kraju oraz wydawcami, księgarzami i twórcami innych nośników informacji, a to w celu wzajemnej wymiany kulturowej". Le biblioteche ecclesiastiche, nr 4. 4. „Wydaje się więc, że nadszedł czas, by konferencje biskupów opracowały na użytek pracowników bibliotek kościelnych «wytyczne dla bibliotek kościelnych» (...) Wytyczne takie winny omawiać problematykę doktrynalną, prawną i praktyczną dotyczącą bibliotek, udzielając wskazówek co do współdziałania z bibliotekami miejskimi; miałoby to na celu umożliwienia szerszego korzystania z bibliotek", tamże, nr 4.7 .

${ }^{118}$ Le biblioteche ecclesiastiche, nr 4. 2.

${ }^{119}$ Pius PP. XII, Adhortatio Apostolica Menti nostrae, pars III.

${ }^{120}$ Sapientia christiana, art. 52.

${ }^{121} \mathrm{Nr}$ 4. 1; por. Schema-tipo di regolamento, art. 18, nr 1.

122 Zwany także „osobą odpowiedzialna za biblioteki kościelne”. Le biblioteche ecclesiastiche, nr 4. 4 .

${ }^{123}$ Sapientia christiana, art. 52.

${ }^{124}$ Ratio fundamentalis institutionis sacerdotalis, $\mathrm{nr} 27$.

125 Tamże. 
ale jednocześnie animatorem kultury, i tym samym pośrednio ewangelizować wspólnotę kościelną, do której przynależy, oraz poszukiwać tych, co pragną pogłębić swoje wiadomości ${ }^{126}$.

Urząd bibliotekarza (dyrektora) mogą pełnić osoby należące do różnych stanów kanonicznych. Mówi o tym List okólny Biblioteki kościelne w misji Kościota: „Papieska Komisja chce podkreślić, jak ważną jest ta odnowa (bibliotek J.A), kładąc nacisk na specjalizację księży, zakonników i świeckich, przeznaczonych do pełnienia, o ile to możliwe, stałej funkcji dyrektorów bibliotek i archiwów oraz opiekunów dzieł sztuki"127.

Trzeba jednak zaznaczyć, że bibliotekarzami są nie tylko dyrektorzy tych instytucji, ale i ich pracownicy „księża, zakonnicy względnie świeccy” 128 .

Biblioteka wtedy działa w sposób sprawny i uporządkowany, gdy ma dostateczną ilość personelu zatrudnionego na stałe ${ }^{129}$. „Co się tyczy bibliotek mniejszych, parafialnych i należących do różnych organizacji, trzeba się raczej odwołać do wolontariuszy, podobnie jak robiono to niegdyś, opierając się na skutecznie pogłębianej wrażliwości wspólnot parafialnych, które kiedyś stworzyły te ośrodki, tak znaczące dla ich wkładu kulturowego"130.

Gdy chodzi o możliwości pracy w bibliotece kościelnej to muszą być to „wykwalifikowani pracownicy"131. Stąd winni zdobyć odpowiednią do pełnionego urzędu formację zawodową ${ }^{132}$, aby posiąść „biegłość w tej materii” ${ }^{133}$.

Jest zrozumiałe, że dyrektor i inni zatrudnieni w bibliotece kościelnej nie mogą poprzestawać tylko na formacji do wykonywania swoich funkcji, lecz muszą ciągle doskonalić swoje kwalifikacje. Stąd biskupi i przełożeni generalni zgromadzeń zakonnych powinni zabiegać o zapewnienie okresowych szkoleń pracownikom podległych im bibliotek ${ }^{134}$.

\section{Zakończenie}

Biblioteki kościelne, w których są zachowane, a także udostępniane powstałe na przestrzeni wieków skarby kultury ludzkiej i chrześcijańskiej, stanowią niewyczerpane bogactwo wiedzy, stąd wspólnota kościelna od początku otaczała te instytucje właściwą troską i opieką. Wyrazem troski władzy kościelnej o tworzenie,

${ }^{126}$ Le biblioteche ecclesiastiche, $\mathrm{nr} 4.1$.

${ }^{127} \mathrm{Nr} 4.2$.

${ }^{128}$ Le biblioteche ecclesiastiche, $\mathrm{nr} 4.7$.

${ }^{129}$ „Wiadomo, że problemem większości bibliotek kościelnych jest cena nowych publikacji i koszt utrzymania samych bibliotek, wymagających pełnego i kompletnego, a więc stałego personelu". Le biblioteche ecclesiastiche, $\mathrm{nr} 4$. 9. Jest oczywiste, że stali pracownicy mają prawo do odpowiedniego wynagrodzenia. Stąd biblioteki muszą być finansowane przez odpowiedzialne za nie instytucje. Por. Le biblioteche ecclesiastiche, nr 4. 9.

${ }^{130}$ Le biblioteche ecclesiastiche, $\mathrm{nr} 4.9$; por. kan. $822 \S 3$; por. Schema-tipo di regolamento, art. $18, \mathrm{nr} 1$.

${ }^{131}$ Tamże, nr 4. 1.

${ }^{132}$ Por. tamże.

${ }^{133}$ Sapientia christiana, art. 54.

${ }^{134}$ Por. Le biblioteche ecclesiastiche, nr 4. 2. 
zachowanie, rozwój i ochronę kościelnych zasobów bibliotecznych, są wydawane w tej materii dyspozycje kanoniczne. Poprzedni, jak i aktualny Kodeks milczy na temat bibliotek kościelnych, aczkolwiek z pewnych przepisów można pośrednio wydedukować, że prawodawca powszechny bierze pod uwagę te instytucje prawne. Natomiast wyraźnie o wspomnianych bibliotekach mówią przedkodeksowe, czy pozakodeksowe dokumenty kanoniczne lub o mające aspekt prawny.

Biblioteka kościelna jest uporządkowanym zbiorem rękopisów, druków lub opracowań i innych środków, mającym na celu przekazywanie tekstów i obrazów, będącym w posiadaniu instytucji aprobowanych albo erygowanych w systemie kanonicznym.

Rozróżnia się podstawowe rodzaje bibliotek kościelnych: Biblioteka Watykańska, biblioteka uniwersytecka, biblioteka biskupia (diecezjalna), biblioteka wyższego seminarium duchownego, biblioteka misyjna, biblioteka kapitulna (katedralna i kolegiacka), biblioteka muzeum diecezjalnego (i kościelnego np. parafialnego), biblioteka sanktuaryjna, biblioteka parafialna.

Podstawą istnienia biblioteki kościelnej jest księgozbiór składający się z różnego rodzaju pozycji obejmujących rozmaite dziedziny wiedzy kościelnej i świeckiej.

Zadaniem biblioteki jest udostępnianie swoich zbiorów zgodnie z prawem uprawnionym osobom (czytelnia, wypożyczalnia).

Biblioteka kościelna to nie tylko księgozbiór, ale instytucja, która planowo gromadzi, opracowuje i udostępnia zbiory oraz informuje o nich. Jest więc zrozumiałe, że musi posiadać właściwą sobie organizację. Na konieczność organizacji wielokrotnie wskazują prawodawcy. Na organizację instytucji bibliotecznej składają się kwestie związane z katalogami, komputeryzacją, z korzystaniem z czytelni i wypożyczalni, czasem pracy, odpowiednim wyposażeniu technicznym oraz odpowiednim personelem. 


\title{
CHURCH LIBRARIES IN THE CANONIC CONTEXT
}

\begin{abstract}
Summary
This article is devoted to church libraries in the canonic aspect. Church library is the institution that collects, prepares and makes collections of books and manuscripts, which are the property of church institutions, available to readers.

In the first part of this article the definition of the church library has been suggested, which is the organized collection of manuscripts, printing or elaborations and other resources, which aims at imparting texts and paintings, which is owned by approved or erected in canonic system institutions.

Afterwards, the problem of library collection has been presented, which is the collection of manuscripts, printing or elaborations and other resources, as well as the issue of the content of these resources. The grading of libraries according to the criterion of the size of the collection of books and manuscripts has also been done. The attention was directed to the problem of maintaining and enlarging the library collection, too.

A lot of attention was given to the organisation of church libraries that not only are the collections of books and manuscripts, but also collect, prepare, make available and inform about collections of books and manuscripts. Within the scope of the organization of church libraries the issue of library, rental and reading room workers has been discussed, as well as the appropriate indemnification of the collection.
\end{abstract}

Translated by ks. Jerzy Adamczyk 